\title{
XXXVI. On metallic sulphurets
}

\section{Professor Proust}

To cite this article: Professor Proust (1805) XXXVI. On metallic sulphurets, Philosophical Magazine Series 1, 21:83, 208-213, DOI: 10.1080/14786440508676704

To link to this article: http://dx.doi.org/10.1080/14786440508676704

$$
\text { 册 Published online: } 18 \text { May } 2009 .
$$

Submit your article to this journal 준

LII Article views: 3

Q View related articles $\asymp$ 


\begin{tabular}{|c|c|c|c|c|c|c|}
\hline & & & & $\mathrm{Yds}$ & It & \\
\hline Ironstone, supposed the logs & & - & + & 0 & 0 & 5 \\
\hline Clod & & - & - & $\mathbf{0}$ & 1 & \\
\hline Coal, mixed with rock & - & - & - & 0 & $\mathfrak{2}$ & \\
\hline Flint coal, or bottom coal & - & - & - & o & 1 & 3 \\
\hline & & & & ] 6 & 0 & \\
\hline
\end{tabular}

We see then, that in the first-mentioned coal pit, no coal was found within much less than 30 yards of the surface, and that then three small layers of bad coal only were gotten : that after sinking near 24 yards deeper, three other layers of the same coal were procured, but that the first vein of good coal lay 92 yards beneath the surface: that this vein was 4 feet thick : that none of the veins appear to have been more than 5 feet thick : and that in 154 yards, and more, regularly worked, or above 254 , taking in the whole experiment, 13 yards 2 feet of coal were found. In the second pit specified, the coal appears to have been met with in little more than 21 yards from the surface. One of the veins proved 6 feet thick; and in sinking somewhat less than 44 yards, above 7 yards thickness of coal was discovered. In the third pit specified, the sulphureous or bad coal was met with in 16 yards from the surface, and good coal in less than 28 yards; no vein exceeded 3 feet; and the aggregate in almost 68 yards was not quite nine yards of coal. In the fourth pit specified, the first unmixed coal was 50 yards from the surface; and in sinking above 116 yards, it does not appear that here was any vein thicker than 2 feet; and the aggregate of unmixed coal measured only 5 feet 2 inches in thickness.

[To be continued.]

XXXVI. On Metallic Sulphurets. By Professor Proust*.

$\mathbf{M}_{\text {ETALs, says Berthollet, may combine in proportions }}$ exceedingly various with sulphur; and the combinations they thus form have different properties, according to their proportions, \&c. Considering the generality with which Berthollet establishes this opinion, there is reason to be astonished that he should have neglected to lay before the reader the facts on which it seems to rest. Silver, mercury, platina, copper, antimony, arsenic, lead, tir, bismuth, \&c.

* From Yournal de Pbysique. 
do not, however, afford one example of variable sulphurations. Iron, hitherto, is the only metal which appears capable of being sulphurated in two proportions, and these, instead of having any thing variable, are on the contrary constant and fixed, as are those of its oxidation.

"I Im in opposition to Proust, who pretends that sulphur has been fixed for iron, by the invariable law of propontions, at 60 per cent."

This result, however, is as certain as invariable, whatever be the number of times the trial is made: he himself gave this opinion, to which Benthollet refuses his assent.

He says, "Pyrites may contain a variable surplus, as far as twenty parts and more, \&c."

I cannot discover a similar variation*. Iron is either at. 60 , or at 90 , or $\mathbf{1 0 0}$. The first sulphuret is that which we usually make in our laboratories, for the decomposition of water; and the second is pyrites itself. In a word, the case with sulphuration of this metal is the same as with oxidation. The principle which presides at one of these combinations, presides certainly at the other; and if neither nature nor art exhibit to us any where intermediate states between these terms, we ought not to be forward to admit variable sulphurations.

"If heat can more easily expel this sulphur, considered as foreign, this is a common property, \&c."

Sulphur separated from iron by the action of fire cannot be qualified with the name of foreign, because it is a necessary element of a combination, which a high temperature destroys, to reduce it to another which can support it. The sulphur which we extract by distillation, from an argil, a sulphate, a stony concretion, \&c. is foreign to their essence, but the same cannot be said of a pyrites. If I made use of these expressions, it was contrary to my intention.

"This chemist admits that black copper is sulphuret dissodved by copper. This solution exhibits in reality ruccessive proportions of sulphur and copper, \&e."

This manner of speaking, employed by Bertbollet, ought to excite surprise : it tends to throw obscurity on distinctions which are however clear. When sulphur is prepared in a copper crucible, a sulphuret of 28 per cent. is obtained, and copper hatding in solution variable quantities of that aulphuset: the laiter may be separated from the coppor

* Fournal de Pbysique, p. 90. vol. liv.

Vot. 21. No. 83. April 1805. 0 without 
without decomposing it. Is this then a simple solution of sulphur in copper? No one will suppose it.

"He pretends that a dose of sulphur invariably fixed by nature, attaches itself to antimony, and that man can neither increase nor diminish it. He fixes this proportion at 25 per cent."

It is not $\mathrm{I}$, but nature, or whatever power you will, which places a barrier betwcen it and the efforts of every chemist who might propose to make sulphuret of antimony beyond or within this proportion: I have not therefore assigned it any law of my invention; I have only verified it. I have followed this precept, which Berthollet himself traces out to us in his profound work. When a substance, therefore, says he, combines with another, we must determine the proportions, examine the properties, \&c. Such indeed has been the constant object of the efforts of chemists since the time when they found that this determination was one of the most important bases of the history of combinations, and of the science of analysis. No one, however, will doubt, that nature cannot abandon her eompounds to the chance of the variable proportions, which Berthollet has chosen as the basis of his system; but it is no less true, that in proportion as the sphere of sulphurets extends, we do not see that the new facts which each day accumulates are of a nature to strengthen it.

"He has however found sulphurets of antimony which had an excess of sulphur. Sulphurets of copper, of lead, \&c., are also found mixed with a like excess." But if it can be taken away without changing their appearance, without taking any thing from the characters and qualities which distınguish these sulphurets, I shall say that this sulphur is foreign to them. The same thing cannot be said of a pyrites, from which has been taken the sulphur, which makes the difference between sulphuret at a minimum, and that at a maximum. That there should be sulphor mixed with sulphurets, without making part of their constitution, is not surprising. We see it every day mixed in the same manner with argil, alum, sulphate of lime, \&c.

"He has combined oxide of antimony with different proportions of sulphuret, and he had mixtures which may be represented by this formula : oxide $+1+2+3$, \&e. of sulphuret of antimony: Has it not thereby formed real combinations? \&c."

I shall reply to this, that solutions begun, or which have not 
not reached the term of saturation of which they are thought to be capable, ought to be considered otherwise than terminated combinations; but to elucidate my idea, I have denoted these solutions as I should denote those of sugar and water: it is water $+1+2+3$, \&c. of sugar.

I cannot see, indeed, that one can form clearcr ideas of the solutions of sulphuret of antimony in its oxide. All chemists have hitherto thought that this glass, this liver, this crocus, were sulphurated oxides. The object of my labour was to undeceive us on this point; to show that it was necessary to renounce these sulphurated oxides, which we admit only on hearsay, in order to receive in their stear, a new kind of combination, no doubt, but which is fully proved to exist. This combination indeed is repugaant to the ideas of Berthollet: he endeavours to place it in the family of the oxides simply sulphurated; but it is no less certain that it exists such as I have announced it, and that it has over that of sulphurated oxides, whose existence is now destroyed, the advantage of giving us the most natural solution of those thousand-and-one antimonial problems, the ridiculous nomenclature of which maintained the confusion of our ideas, and covered the history of antimony with profound obscurity. Berthollet adds, repeating my expressions: "I do not see how this saves the oxides of that metal from the suspicion of being able to unite with sulphur in all doses, and without regard to the invariable laws of proportion; but he must however admit, that these laws are not invariable, and must limit his apothegm, in regard to the proportions of the sulphuret of antimony with its oxide."

This paragraph requires that I should divide my answer into two parts. I will then first observe, that Berthollet, by introducing here the solution of sulphur in an oxide, when the question is merely that of a sulphuret, changes his subject: for the solution of sulphur, and that of the sulphuret, in the same excipient, are no more comparable than those of sulphur and sulphuric acid in the same liquor.

I will next say in reply, that not only the solubility of a metallic sulphuret in its oxide saves the latter from the suspicion of being able to unite with sulphur in all doses, which among us, the old disciples of Macquer, Rouelle, \&c., was an error difficult to be eradicated; but it saves it also from another, which it is of no less importance to explain, that of dissolving a metal, and in all sorts of proporions, since indeed it exists as such in crocus and ruby. I shall $\mathrm{O} 2$ therefore 
therefore beg Berthollet to make himself for a moment author of the doctrine which he combats, and ask him what he would think of a chemist, who, for the good of the contrary bypothesis, should employ himself in arranging on one side all the considerations which he could deduce from the metal which ought to throw light on the nature of livers of antimony, to arrange then, exclusively, the latter, on the sulphur they contain? Why, would he say, are you silent in regard to that metal which lies close to sulphur, and which can so well remove whatever is difficult to be conceived in the solution of the latter by an oxide? Each of us then resuming the hypothesis he defends, I will answer the objection of Berthollet, by begging him not to forget, that if in the crocus there is sulphur in all doses, it is to saturate this sulphur that there is metal also found in all doses. This is what has obliged me not to range in the same line the sulphurated oxides of antimony, if any remain, with oxides holding in solution sulphuret, which will hereafter supply their place.

In regard to the nature of these combinations, the aspect under which I have presented them is far from furnishing limits to my apothegm, to deduce from it arguments against the law of proportions. He ought to have determined, that oxide of antimony may attain the term of its saturation by dissolving sulphuret, and thus to have discovered, that he cannot thence adduce an appearance and characters which warrant the constancy of this saturation, as generally happens to all the combinations which range themselves under the law of proportions. If the case with an oxide, in the power it has of dissolving, were the same as that of an acid which retains its liquidity, nothing would be easier than to resolve the question, and I should have employed myself on it. But when an oxide of antimony, to which is added a little sulphuret, has assumed the colour and transparency we require in it, we stop it there, without paying attention to the weight and measure, because it is in this state that we wish to have it. This is glass of antimony; a new dose of sulphuret makes it crocus; a greater makes it hepar, and so on ; that is to say, the old chemists, without paying regard to a theory, the knowledge of which was reserved for posterity, broke down the solution of sulphuret in its oxide, and extracted from the crucible, as one may say, each of the fractions to fill the repositories of medicine with their livers, their magisteries, their rubies, and their diaphoretics, from Basil Valentine down to Lemery. Such, in my opinion, is the whole history of antimony. To a pound 
of potash, add an ounce of arsenic, it will not be saturated; if you add two and a third, the case will be the same, and so on : but till the point of this saturation be discovered, I must repeat to them, your arsenical potash hitherto has been nothing but potash $+1+2+3$ of arsenic; but as I have not yet had time to verify whether the combination will obey, as there is ro reason to doubt, the law of relations, we must not be too urgent to deduce from them conclusions. To conclude, these are results so variable, that they annihilate your laws of proportion, and render your apothegms illusory. Besides, Berthollet is too just not to allow, that the series of the numbers by which I have endeavoured to represent the solutions of sulphuret of antimony in its oxide, has not the least relation with what I have hitherto called proportion in combinations.

XXXVII. An Analysis of the magnetical Pyrites; with Remarks an some of the ather Sulphurets of Iron. By Charles Hatchett, Esq. E. R.S.

[Concluded fiom p. 147.]

\section{$\S$ VIII.}

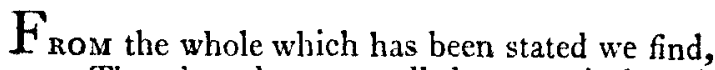

1. That the substance called magnetical pyrites, which has hitherto been found only in Saxony and a few other places, is also a British mineral, and that, in Caernarvonshire, it forms a vein of considerable extent, breadth, and depth.

2. That the component ingredients of it are sulphur and metallic iron; the former being in the proportion of 36.50 or 37 , and the latter about 63.50 or 63 .

3. That the chemical and other properties of this substance are very different from those of the common martial pyrites, which, however, are also composed of sulphur and iron, varying in proportion, from $52 \cdot 15$ to $54 \cdot 34$ of sulphur, and from $47 \cdot 85$ to 45.66 of metallic iron: the difference between the common pyrites which were examined being therefore $2 \cdot 19$, and the mean proportions amounting to 53.24 of sulphur, and 46.75 of iron; consequently, the difference between the relative proportions, in the composition of the magnetical pyrites and of the common pyrites, is nearly $] 6 \cdot 74$ or $16 \cdot 24$.

4. That, as the magnetical pyrites agrees in analytical $\mathrm{O}_{3}$ results, 